\title{
Sensorial analysis and electronic aroma detection to compare olive oils produced by different extraction methods
}

\author{
By L.T. Vaz Freire ${ }^{\text {a }}$, M.J.Cabrita ${ }^{\text {a }}$, M.D.R. Gomes da Silva ${ }^{b}$ and A.M. Costa Freitas ${ }^{\text {a }}$ \\ ${ }^{a}$ Escola de Ciências e Tecnologia, Departamento de Fitotecnia, Instituto de Ciências Agrárias e Ambientais \\ Mediterrânicas ICAAM, Universidade de Évora, Apt 94, 7002-554 ÉVORA, Portugal \\ ${ }^{\mathrm{b}}$ REQUIMTE, Departamento de Química, Faculdade de Ciências e Tecnologia/ Universidade Nova de \\ Lisboa, Campus da Caparica 2829-516, Portugal \\ ( ${ }^{*}$ corresponding author: afreitas@ @uevora.pt)
}

\section{RESUMEN}

Análisis sensorial y detección electrónica de aromas para comparar aceites obtenidos por diferentes métodos de extracción.

El análisis sensorial y el análisis de aromas por medio de sistemas sensoriales electrónicos han sido utilizado para comparar aceites de oliva producidos a través de dos sistemas de extracción diferentes.

Los métodos de extracción comparados han sido el sistema de prensas y el decantador de dos fases. Las muestras fueron producidas durante las cosechas del periodo 2002 2004, y las aceitunas eran todas de la misma variedad portuguesa Gallega sp. Las aceitunas fueron seleccionadas y tratadas tecnológicamente bajo condiciones predeterminadas y supervisadas. Los aceites producidos resultaron mejor clasificados cuando fue aplicado el análisis sensorial por panel que cuando se utilizó el análisis con detección electrónica de aromas, incluso después de la optimización de los sensores. Esta observación está de acuerdo con el hecho de que los aceites son una matriz poco volátil y que es el "flavour", más que el aroma, el que junto con el gusto puede proporcionar una caracterización mejor que la detección electrónica, en la que el aroma es la principal característica evaluada.

PALABRAS CLAVE: Aceite de oliva - Análisis Sensorial - Aroma - Detección electrónica de aromas - Sistema de extracción.

\section{SUMMARY}

Sensorial analysis and electronic aroma detection to compare olive oils produced by different extraction methods.

A sensorial analysis and an aroma analysis by electronic sensory devices were used to compare olive oils produced according to two different extraction methods.

The extraction methods compared were the press system and two phase decanter. Samples were taken from the harvests of 2002-2004 and the olives were all from the same variety. The variety used was the Portuguese Galega sp. Olives were picked and technologically handled under predetermined and supervised conditions. Olive oils produced were better classified when the sensory analysis by a panel was applied than when an electronic sensory analysis was performed, even after sensor optimization. This observation is in accordance with the fact that olive oil has a low volatility matrix and "flavor", rather than aroma, can give a clearer characterization than electronic sensory analysis alone, where aroma is the main characteristic evaluated.

KEY-WORDS: Aroma - Electronic nose - Extraction technology - Olive oil - Sensorial analysis.

\section{INTRODUCTION}

Food consumption is intrinsically connected to the stimulation of the human senses, namely taste and smell. The sence of smell is stimulated by the reception of a complex mixture of compounds, usually hydrophobic, from quite a large spectra of molecules which might be present under different concentrations, some of them even extremely low (Blake, 2007). The persistent and resident time of the aroma is usually related to the volatility of the compounds responsible for the smell. The aroma perceived by the nose is sent to the brain for identification (Smith et al., 2001).

In order to "feel" the taste the mixed matrix has to be solved. The term usually used, "flavor", combines taste and aroma sensations.

So far, several compounds belonging to different chemical families have been identified in olive oil. Most of the volatile compounds in olive oil are formed after the oxidation of free fatty acids either by auto-oxidation, enzymatic oxidation or photooxidation (Gouveia 1995; Cavalli et al., 2004). Enzymatic oxidation, catalyzed by lypoxigenase, is the most common pathway. These enzymes are able to catalyze oxidation from polyunsaturated fatty acids namely linoleic and linolenic acids. The enzyme becomes active as soon as the fruit is destroyed by crushing during extraction. This pathway is usually referred to whenever a fruit is exposed to stress conditions such as picking, crushing, warming, etc (Morales et al., 1997; Morales et al., 2000; Ridolfi et al., 2002; Vichi et al., 2003; Angerosa et al., 2004; Cavalli et al., 2004; Marques et al., 2007).

This oxidation mechanism is responsible for the production of hexanal, cis-3-hexenal (with a 
greeny/grassy sensorial note) as well as the cis3-nonenal, cis, cis-3,6-nonadienal (with olfactory perceptions of "cucumber" and "apple"). These aldheydes are respectively transformed into $\mathrm{C}_{6}$ and $\mathrm{C}_{9}$ alcohols and esters (Morales et al., 1997; Morales et al., 2000; Ridolfi et al., 2002; Vichi et al., 2003; Angerosa et al., 2004; Cavalli et al., 2004; Marques et al., 2007).

Olive oil sensory characteristics are the main consideration to determine consumer acceptance. High quality olive oils have a volatile profile whose balance in the oil allows for the designation of the positive attributes "fruity" or "green". These positive attributes can be diminished by the presence of negative sensorial notes that will depreciate the initial pleasant ones. Defects are identified as belonging to four main groups "mouldy", "winey", "buttery" and "fusty". Each of these defects presents a perfectly distinct volatile profile (Angerosa et al., 2004; Morales et al., 2004; Vaz-Freire et al., 2008).

"Mouldy", "winey" and "fusty" are usually associated with defective storing conditions before extraction, while "buttery" is associated with a defective olive oil storage (Morales et al., 2004).

The degree of consumer acceptance depends on the degree of intensity of each defect. CE regulation no1989 from 2003 classifies the olive oils as "lampantes" whenever a defect's intensity is too high. These olive oils are not acceptable for human consumption.

A sensorial analysis can be defined as a discipline used to measure, analyze and interpret the reactions to food product characteristics by our senses (Ardeshir, 1993).

A sensorial analysis uses the human senses as a measuring tool, although as a more precise tool, it depends on previous stimulus as well as the physiological, psychological and social condition of the tasters (Blake, 2007). The food Industry uses these parameters in a very precise, but rather expensive way.

The sensorial analysis can be classified as discriminative when it indicates the presence or absence of differences (Poste et al., 1986; Lyon 1987) or it can be descriptive whenever the intensity of the differences is to be evaluated (Poste et al., 1986; Lyon 1987; Verrelli 2008).

For a sensorial analysis concerning taste and aroma COI (international olive council) is normalizing the analytical methodology going as far as the normalization of glasses, rooms and environmental conditions as well as selection, training and recycling of tasters besides vocabulary and final classification of the different attributes (COI/T.20/Doc. no. 5, 1987; COI/T.20/Doc. no. 6 , 1987; COI/T.20/Doc. no. 13/Rev.1, 1996; COI/T.20/ Doc. no. 15/Rev.1, 1996; IOOC - Resolution no. RES-3/75-IV/96, 1996).

Since 1991, the sensorial analysis coupled with a fixed and extensive group of chemical and physical analyses are necessary, according to the CEE regulation №2568/91 (European Commission, 1991), with the corrections introduced by the CEE regulation №796/2002 (European Commission, 1992) to correctly classify virgin olive oil according to the COl's established conditions.

The main issue of some of these recommendations and regulations is probably the fact that although the sensorial analysis is well established and considered, it is rather difficult and expensive to train a sensorial panel, besides the fact that not everyone can be trained as a panellist.

Bearing this in mind and, in order to try to obtain more routine and "unspecialized" results, we used electronic sensory analysis (sometimes called "electronic nose"). The basis of an "electronic nose" is the use of a matrix of non-selective chemical sensors, (usually polymeric or metallic oxides) along with complex statistical treatment, to mime the human olfactory system and the human brain. The sensors will receive the chemical information, carried by the vapour above the sample and after the generation of some mathematic algorithms, the processed information is translated into a two dimensional plot similar to a "fingerprint" information of the aroma (Brezmes et al., 2007; Sousa et al., 2007). Currently a specialized instrument, specific to olive oils, is being developed (Brezmes et al., 2007). The main difference from the "normal" instruments is the specificity of the sensors adjusted to the matrix.

\section{MATERIALS AND METHODS}

\subsection{Sample preparation}

Experiments were carried out by mechanically processing picked olives of the Portuguese cultivar Galega Vulgar. All olives were picked according to proper controlled sanitary conditions. Olives were picked during the harvests of 2001, 2002, 2003 and 2004.

From each cultivar a $120 \mathrm{Kg}$ sample was collected. Fruits were stored in open boxes at ambient temperature $\left(5-15^{\circ} \mathrm{C}\right)$ with reasonable air flow and without direct light incidence. Extraction was done during the next $24 \mathrm{~h}$. Before extraction, leaves and dirt were removed by washing under cold running water.

\subsection{Extraction Technology}

An homogeneous $20 \mathrm{Kg}$ sample was processed for each of the technologies under study: a hammer-mill press line (Vieirinox, Portugal) and a hammer-mill integral decanter line (Oliomio, Italy) were used. No water was added to the olive paste in both systems and malaxation time, about $1 \mathrm{~h}$, was the same for both methods. Three replicates were made for each extraction /season.

\subsection{Chemical analysis: acidity, UV spectroscopy, peroxide index}

Acidity, UV spectroscopy and peroxide index were determined according to CE regulation nr. 2568/91. Results refer to the mean value of the replicates. 


\subsection{Sensorial Analysis}

\section{Pannel sensory analysis}

A sensorial analysis was performed according to the rules established by the COI and CEE (IOOC Resolution no. RES-3/75-IV/96, 1996; Regulation (CEE) no2568/1991; Regulation (EC) no 1989/2003). The panel had seven well trained tasters, trained to discriminate olive oil attributes. The sensorial analysis was performed in a sensory room. The room was isolated with an environmental temperature of $20-22^{\circ} \mathrm{C}$ and a relative humidity between $60-70 \%$.

The samples were poured into adequate dark glasses and presented, anonymously, to each taster, at a temperature of $28 \pm 2^{\circ} \mathrm{C}$ covered by a watch glass. Apple slices as well as water glasses were present as palate cleansers. The three replicates of each extraction were considered as one batch and from each batch three samples were considered for the sensory analysis. Analyses were carried out on consecutive days.

Each taster smelled and tasted the olive oil and registered the intensity due to each positive and/ or negative attribute percieved. The results were written on a normalized profile sheet adapted by Laboratório de Estudos Técnicos ISA/UTL, Lisbon in accordance to Regulation (EC) ํo 1989/2003, (Table1).

Table 1

\begin{tabular}{|c|c|c|c|c|c|c|c|c|c|}
\hline \multicolumn{7}{|c|}{ Smell-taste-touch notes } & \multicolumn{3}{|c|}{ Punctuation Table } \\
\hline \multirow[b]{2}{*}{ Attribute } & \multicolumn{6}{|c|}{ Intensity of perception ${ }^{(2)}$} & \multirow{2}{*}{$\begin{array}{l}\text { Defects } \\
\text { None }\end{array}$} & \multirow{2}{*}{$\begin{array}{l}\text { Characteristics } \\
\text { Fruity olive or } \\
\text { fruity from other } \\
\text { fruits }\end{array}$} & \multirow{2}{*}{$\begin{array}{c}\begin{array}{c}\text { Global } \\
\text { Evaluation }\end{array} \\
9 \\
8 \\
7\end{array}$} \\
\hline & 0 & 1 & 2 & 3 & 4 & 5 & & & \\
\hline Fruity Olive (mature or green) ${ }^{(1)}$ & & & & & & & $\begin{array}{l}\text { Light or almost } \\
\text { unnoticed }\end{array}$ & Very slightly fruity & 6 \\
\hline Apple & & & & & & & Perceptible & $\begin{array}{l}\text { Fruity but with slight } \\
\text { defects or other } \\
\text { taste or smell } \\
\text { abnormal }\end{array}$ & 5 \\
\hline Other mature fruits & & & & & & & $\begin{array}{l}\text { Perceptible but } \\
\text { still acceptable }\end{array}$ & $\begin{array}{l}\text { Fruity but with } \\
\text { strong defects and } \\
\text { unpleasant taste } \\
\text { and smell }\end{array}$ & 4 \\
\hline Green (leaves, grass) & & & & & & & $\begin{array}{l}\text { Very strong } \\
\text { and very } \\
\text { perceptible }\end{array}$ & $\begin{array}{l}\text { Taste and smells } \\
\text { totally unacceptable } \\
\text { for consumption }\end{array}$ & $\begin{array}{l}3 \\
2 \\
1\end{array}$ \\
\hline \multicolumn{10}{|l|}{ Bitter } \\
\hline \multicolumn{10}{|l|}{ Pungent } \\
\hline \multicolumn{10}{|l|}{ Sweet } \\
\hline \multicolumn{10}{|l|}{ Other(s) acceptable attribute (s) } \\
\hline Which? & & & & & & & Name & & \\
\hline \multicolumn{10}{|l|}{ Acid/sour/winey } \\
\hline Muddy sediment & & & & & & & \multirow[t]{2}{*}{ Sample Code } & & \\
\hline \multicolumn{9}{|l|}{ Metallic } & \\
\hline \multicolumn{10}{|l|}{ Musty - humid } \\
\hline \multicolumn{10}{|l|}{ Fusty } \\
\hline \multicolumn{10}{|l|}{ Rancid } \\
\hline \multicolumn{10}{|l|}{ Other unacceptable attribute(s) } \\
\hline Which? & & & & & & & & & \\
\hline $\begin{array}{l}\text { 1) Scratch the unnecessary preception } \\
0=\text { total absence } \\
1=\text { almost unnoticed; } 2=\text { slight; } 3=\end{array}$ & & & & & & & & & \\
\hline
\end{tabular}




\section{Electronic sensory analysis}

The Electronic sensory analysis device used was an Alpha MOS FOX 3000, equipped with 12 metal oxide sensors: SYLG, SYG, SYAA, SYGH, SYGCTI, SYGCT, T301, P101, P102, P401, T702, and PA2 (Table 2). $T$ and $P$ are metal oxide with $\mathrm{SnO}_{2}$ as semiconducting material, the difference between these two types of sensors is only related to the geometry of the sensors. On type T sensors the sensitive material is placed into an aluminium tube $(T)$ while type $P$ is a flat sensor. SY sensors are metal oxide sensors with a Titanium and Chromium oxide $\left(\mathrm{Cr}_{2-\mathrm{x}} \mathrm{Ti}_{\mathrm{x}} \mathrm{O}_{3+\mathrm{y}}\right)$ and a Tungsten oxide $\left(\mathrm{WO}_{3}\right)$.

The sample headspace is carried through the sensors by a flow of continuous extra pure compressed air at a flow rate of $150 \mathrm{ml} / \mathrm{min}$. For electronic sensorial analysis, the conditions used were: headspace development: incubation time $300 \mathrm{sec}$ at $40^{\circ} \mathrm{C}$; agitation speed $750 \mathrm{rpm}$; syringe temperature: $45^{\circ} \mathrm{C}$; injection volume: $500 \mathrm{ml}$; injection speed $500 \mathrm{ml} / \mathrm{sec}$; acquisition time, $120 \mathrm{sec}$ with a period of $0.5 \mathrm{sec}$

\subsection{Statistical analysis}

A univariate statistical analysis as well as PCA ("Principal Component Analysis") were made using the Statistica 6.0 software (Stat Soft, Inc, USA).

\section{RESULTS AND DISCUSSION}

\subsection{Sensorial analysis}

The monovarietal olive oils from the Galega variety showed rather scattered sensorial values allowing the samples from the two extraction methods used to be classified according to CE regulation nr. 1989 (2003), from lampante (unacceptable for human consumption) to extra virgin olive oil. The analytical results associated to this classification were acidity, $\mathrm{K}$ and peroxide index. According to regulation CE 2568/91, based on the sensorial analysis alone, Galega olive oils never get the lampante classification which is attributed to a sensorial final score below 3.5 (Table 3).

Table 2

Sensor types and volatile descriptors

\begin{tabular}{ll}
\hline Sensors & Description of volatiles analyses \\
\hline P101, P102, SYGCT & $\begin{array}{l}\text { Non-polar volatiles, methane, propane, hydrogen bonding } \\
\text { compounds, aldehydes } \\
\text { PA2, SYAA, T301 }\end{array}$ \\
Polar compounds, alcohol \\
Alcohol, aromatic compounds \\
P401, SYLG & Ammonia and ammonia derivatives, sulfur, amines and amine \\
\hline
\end{tabular}

Table 3

Sample classification according to the sensory panel results

\begin{tabular}{|c|c|c|c|c|c|c|c|c|}
\hline $\begin{array}{l}\text { Technology/year } \\
\text { (1)Attributes }\end{array}$ & $\begin{array}{c}\text { Two } \\
\text { phase } \\
2001(n=3)\end{array}$ & $\begin{array}{l}\text { Press } \\
2001 \\
(n=3)\end{array}$ & $\begin{array}{c}\text { Two } \\
\text { phase } \\
2002(n=3)\end{array}$ & $\begin{array}{l}\text { Press } \\
2002 \\
(n=3)\end{array}$ & $\begin{array}{c}\text { Two } \\
\text { phase } \\
2003(n=3)\end{array}$ & $\begin{array}{l}\text { Press } \\
2003 \\
(n=3)\end{array}$ & $\begin{array}{c}\text { Two } \\
\text { phase } \\
2004(n=3)\end{array}$ & $\begin{array}{c}\text { Press } \\
2004 \\
(n=3)\end{array}$ \\
\hline Fruited (mature and green) & 1.5 & 1.3 & 1.2 & 1.8 & 1.5 & 2.7 & 2.2 & 0.7 \\
\hline Apple & 0 & 0 & 0 & 0.3 & 0.3 & 0.8 & 0.5 & 0.0 \\
\hline Other mature fruits & 0 & 0 & 0 & 0 & 0 & 0.3 & 0 & 0.5 \\
\hline Green & 0 & 0 & 0 & 0 & 0 & 0.7 & 0.7 & 0.2 \\
\hline Bitter & 0 & 0 & 0 & 0 & 0 & 0.8 & 0.2 & 0.3 \\
\hline Pungent & 0 & 0 & 0 & 0.7 & 0.0 & 1.7 & 0.5 & 0.3 \\
\hline Sweet & 0 & 0 & 0 & 1.0 & 0.3 & 1.2 & 0.7 & 0.5 \\
\hline Other acceptable attributes Which? & 0 & 0 & 0 & 0 & 0 & 0 & 0 & 0 \\
\hline Winey/acid & 0 & 0 & 0 & 0 & 0 & 0 & 0 & 0 \\
\hline Metallic & 0 & 0 & 0 & 0.3 & 0 & 0 & 0 & 0 \\
\hline Musty-Humid & 1.5 & 0.8 & 2.7 & 0 & 2.7 & 0.0 & 0.8 & 3.0 \\
\hline Fusty & 0 & 0 & 0.0 & 0 & 0 & 0 & 0 & 0 \\
\hline Mouldy & 0 & 0 & 0.5 & 0.3 & 0 & 0 & 0 & 0 \\
\hline Rancidity & 0 & 0 & 0.0 & 0.0 & 0 & 0 & 0 & 0 \\
\hline Other unacceptable attributes & 0.8 & 1.5 & 0.0 & 0.8 & 0 & 0.5 & 0 & 0 \\
\hline (2)Final punctuation & 5.5 & 5.5 & 4.8 & 6.2 & 4.0 & 7.3 & 6.3 & 3.8 \\
\hline
\end{tabular}

(1) $0=$ total absence; $1=$ almost undetected; $2=$ light; $3=$ medium; $4=$ intense; $5=$ extreme

(2) $9-7=$ no defects; $6=$ defects light or almost undetected; $5=$ detected; $4=$ limit of accepted defects; $3-1=$ very strong defects 
When an univariate test of significance (twoway ANOVA) was applied, no significant differences $(P>0,05)$ were found among the different olive oils when year or extraction methods were considered. However, when year/extraction interaction was considered a significant difference $(P<0,05)$ among olive oils was observed $(P=0,014)$. According to figure 1, olive oils produced in years 3 and 4 (2003, 2004) seem to be the ones mainly responsible for the significant differences observed. Results are not in agreement with others who noticed a clear impact on year over cultivar (Gracia et al. 200) probably due to the fact that we were looking just to one cultivar and we considered only acidity, $\mathrm{K}$ and peroxide index. In fact, differences among cultivars are more evident when volatiles, fatty acids and sterol composition are considered (Vekiari et al. 2010).

When we analyzed the scores given to the samples in which the "musty-humid" attribute is perceived, we could detect a direct relation $\left(r^{2}=0,8638\right)$ between this attribute and the mean score given by the panel, implying a direct impact, of this attribute, for olive oil classification. The "musty-humid" attribute is usually associated to very long filtration processes or excessive contact time with lees.

When PCA analysis was made using the different parameters (attributes in table 2) used for sensorial analysis we could verify a trend, showing that decanter extraction technology produces more consistent scores (over the years) than the press system (Figure 2).

\subsection{Electronic sensory analysis}

Data obtained from the electronic sensory analysis was also submitted to PCA analysis, using the specific software of the Alpha Mos instrument. As in any usual PCA analysis the basic principle is to rewrite the original variables into new ones. These new variables are plotted in the two dimensional space by transforming the original coordinates (Ferreira et al., 2002).

The discrimination index obtained gives a clear indication of the separation observed among groups. Negative discrimination indexes reveal overlapping samples/groups while a positive discrimination index shows a clear separation among sample/groups; when the index lies between 80-100, a perfect separation is obtained.

When the complete set of sensors are used (description associated to the sensors are shown in Table 2) no clear separation could be perceived and the discrimination index was -38. Since the instrument software allows an automatic selection of sensors, we used this feature to optimize the separation (Figure 3). As can be seen the two first PCA's (PC1 and PC2) account for a total variance of $100 \%(99,49 \%$ PC1 and 0,51\% for PC2), however the discrimination index which is used to explore the data and to assess discrimination performance, giving an indication on the discrimination quality, is still negative thus a clear separation cannot yet be considered and an overlapping of samples/groups can be understood.

It has already been shown that the vulgar volatile composition of the Galega cultivar (Vaz Freire and al, 2009) is characterized by a reduced number of compounds which include an intense peak of hexen-2-al as well as other compounds with 6 carbon atoms, like Z-2-hexenol, E-3-hexenol, Z-3-hexenol when analysis is made by SPME/ GCMS. This small number of compounds might

year*extraction method; LS Means

Current effect: $F(3,16)=4,8175, p=, 01414$

Effective hypothesis decomposition

Vertical bars denote 0,95 confidence intervals

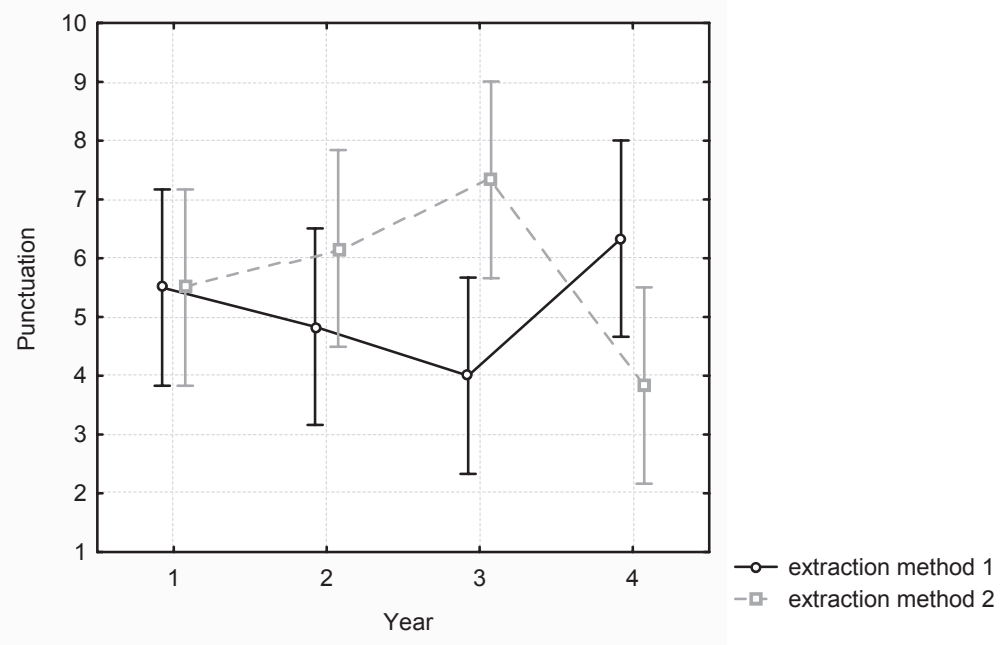

Figure 1

Effective hypothesis decomposition for Galega Vulgar, year and extraction method (Vertical bars denote 0.95 confidence intervals). 
Projection of the cases on the factor-plane $\left(\begin{array}{ll}1 \times 2 & 2\end{array}\right)$

Cases with sum of cosine square $>=0,00$

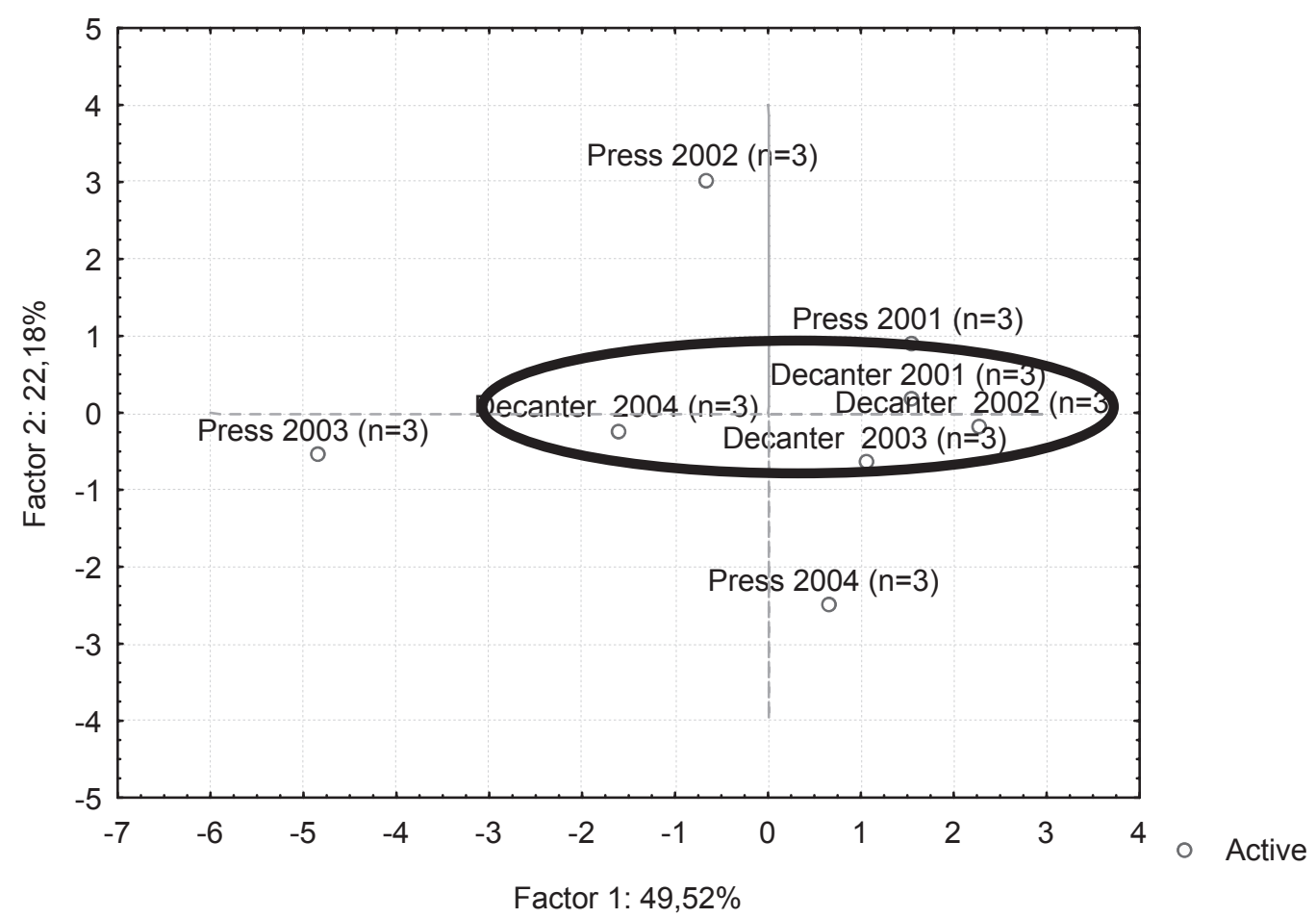

Figure 2

Projection of the cases on the factor-plane $(1 \times 2)$ for correlation matrix.

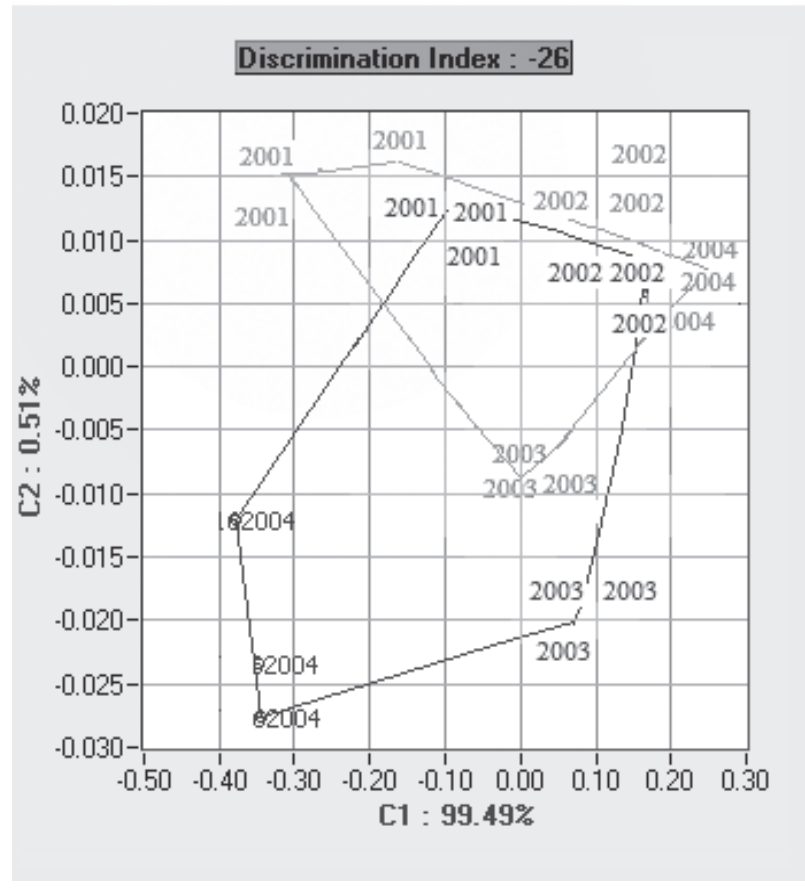

Figure 3

Plot of the PCA analysis of olive oil samples obtained during the studied years by two different extraction technologies using an optimized set of sensors of the Alpha Mos instrument; - - press system; — - two phase decanter. explain the low discrimination obtained and can help understand which were the discarded sensors, SYG, SYGH, SYGCTI, which are mainly related to the detection of ammonia and ammonia derivatives, sulphur, amines and amine containing compounds. Moreover, the final result is also affected by the fact that the remaining sensors are all sensitive to similar compounds like alcohols and aldehydes (Table 1), which are exactly the dominant volatiles of the aroma fraction of the Galega olive oil.

Our results are not in accordance with previous ones that used an e-nose (zNoseTM 7100 vapor analysis system, EST, Newbury Park, CA, USA), consisting of a 1-m DB-5 column and a SAW detector with a parts per billion sensitivity (Kadirog lu et al. 2010), in combination with chemometrics, and were able to separate extra virgin olive oils, according to the cultivar, geographical origin and harvest year. Also García -González et al. (2010) coupled the e-nose with GC, generating a so-called sensogram, and proved the sensor sensitivity towards alcohols, aldehydes and other compounds known as responsible for sensory defects in virgin olive oil. The use and comparison of the e-nose with the sensory analysis by a panel was not reported, however the need for a specialized e-nose for olive oil analysis with tailor made sensors was reported, namely for authenticity and detection of taints (Berna 
A. 2010). These results support our conclusions that electronic detection in a non-volaile matrix such as olive oil, is not a straightforward analysis and results need careful interpretations.

\section{CONCLUSIONS}

A clear separation, among olive oils produced from the Galega olives during the harvests of 20012004 using different extraction procedures could not be detected using the electronic sensory device alone. Sample complexity, as well as low volatility and small concentration of important volatiles is probably responsible for these results (Drake et al., 2003).

The sensorial analysis seems to be more effective in perceiving slight differences. These results might be explained by the complex set of compounds that account for the sensorial results (where samples are smelled and tasted) and not for the electronic sensing where just volatiles are perceived.

The results are in accordance with the fact that fraud in olive oil is usually detected by a complete set of analysis and sensorial analysis alone is not able to detect and confirm fraud.

\section{AKNOWLEDGMENTS}

Authors wish to acknowledge the members of the sensory panel specially Prof. J. M. Gouveia responsible for the panel, as well as Fundação para a Ciência e Tecnologia, MCTES, and MADRP, Portugal for funding. Projects: SFRH/BD/8890/2002 and Agro 824.

\section{REFERENCES}

Ardeshir, H. 1993 There's no accounting for taste: or is there? Nutrition \& Food Science 88, 10-12.

Angerosa F, Servili M, Esposto S. 2004. Volatile compounds in virgin olive oil: occurrence and their relationship with quality. J. Chromatogr. A 1054, 17-31.

Berna A. 2010. Metal Oxide Sensors for Electronic Noses and Their Application to Food Analysis. Sensor 10, 3882-3910.

Blake AA. 2007. Flavour Perception and the Learning of Food Preferences, in A. J. Taylor and D. D. Roberts, editors Flavor Perception. Blackwell Publishing Ltd. Oxford, UK. doi: 10.1002/9780470995716. ch6

Brezmes J, Cabré P, Rojo S, Llobet E, Vilanova X, Correig X. 2007. Identificación de diferentes tipos de aceite de oliva mediante una nariz electrónica con sensores comerciales y algoritmos de procesado de señal. Available from: http://www.percepnet.com/ tecno07_02.htm.

Cavalli JF, Fernandez X, Loiseau A. 2004. Characterization of volatile compounds of French and Spanish virgin olive oils by HS-SPME: identification of qualityfreshness markers. J. Agric. Food Chem. 88, 151-157.

Ferreira E, Rodrigues S, Ferreira M, Nóbrega J. 2002. Análise Exploratória dos Teores de Constituintes Inorgânicos em Sucos e Refrigerantes de Uva. Eclet Química 27, 77-90.
García-González DL, Aparicio R. 2010. Coupling MOS sensors and gas chromatography to interpret the sensor responses to complex food aroma: Application to virgin olive oil. Food Chem. 120, 572-579.

Gracia MS, Royo A, Guillén M. 2009. Composición química de aceites de las variedades Arbequina y Empeltre cultivadas en regadio. Grasas Aceites 60, 321-329.

Gouveia JM. 1995. Azeites virgens do Alto AlentejoComportamentos químicos,

tecnológico, e sensorial. (DPhil. Dissertation) PhD. UTL, ISA, Lisboa, Portugal 542 p.

International Olive Oil Council Resolutions. Madrid, 20 November 1996 COI/T.20/Doc. no. 13/Rev.1. Sensory analysis of olive oil- Standard- General methodology for the organoleptic assessment of virgin olive oil.

COI/T.20/Doc. no. 15/Rev.1. Sensory analysis of olive oilMethod- Organoleptic assessment of virgin olive oil. RES-3/75-IV/96, Revised method for the organoleptic assessment of virgin olive oil.

COI/T.20/ Doc. no. 14/Rev.1. Sensory analysis of olive oil-Standard- Guide for the selection, training and monitoring of skilled virgin oil tasters. International Olive Oil Council Resolutions. Madrid, 18 June 1987

COI/T.20/Doc. no. 5. Sensory analysis of olive oil- Standard Glass for the oil tasting.

COI/T.20/Doc. no. 6. Sensory analysis of olive oil- StandardGuide for the installation of a test room.

Kadirog lu P, Korel F, Tokatlı F. Classification of Turkish Extra Virgin Olive Oils by a SAW Detector Electronic Nose. J. Am. Oil Chem. Soc. DOI 10.1007/s11746010-1705-8 (published on-line 5 Nov. 2010).

Lyon BG. 1987. Development of chicken flavour descriptive terms aided by multivariate statistical procedures. J. Sens. Stud. 2, 55-67

Marques PA, Vaz-Freire L, Freitas AM. 2007. Comparação de alguns compostos do aroma de azeites obtidos por dois métodos de extracção diferentes. Rev Ciências Agrárias 183-186.

Morales MT, Luna G, Aparicio R. 2004. Comparative study of virgin olive oil sensory defects. Food Chem. 91, 293-301.

Morales MT, Luna G, Aparicio R. 2000. Sensory and chemical evaluation of winey-vinegary defect in virgin olive oils. Eur. Food Res. Technol . 211, 222-228.

Morales MT, Rios J, Aparicio R. 1997. Changes in the volatile composition of virgin olive oil during oxidation: flavours and off-flavours. J. Agri. Food Chem. 45, 2666-2673.

Moita Neto JM. 2004. Estatística Multivariada: uma visão didática- metodológica. Crítica - Revista de filosofia e ensino (serial on-line). Available from http://criticanarede. com/cien_estatistica.html. Posted $9^{\text {th }}$ May 2004.

Poste LM, Willemon C, Butler G, Patterson C. 1986. Sensory Aroma Scores and TBA Values as Indices of Warmed-Over Flavour in Pork. J. Food Sci. 5, 886-888.

Regulation (EC) n-2568/1991 of Commission of 11 of July; Official Journal of Europeans Communities, L248, 5 September 1991.

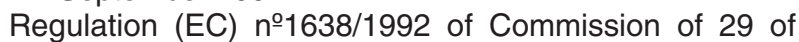
June; Official Journal of Europeans Communities, L176/27, 30 June 1992.

Regulation (EC) no 1989/2003 of 6 November 2003 amending Regulation (EEC) No 2568/91 on the characteristics of olive oil and olive-pomace oil and on the relevant methods of analysis.

Ridolfi M, Patume M, Fontanazza G. 2002. Characterization of the lipoxygenases in some cultivars and determination 
of their role in volatile compounds formation. J. Agric. Food Chem. 50, 835-9.

Smith DV, Margolskee RF. 2001. Making Sense of Taste. Scient. American 284, 32-9.

Sousa A, Carvalho P. 2007. Utilização de Sensores no Ensino das Ciências. Departamento de Física, Faculdade de Ciências da Universidade do Porto. Availablefrom:http://eec.dgidc.min.edu.pt/documentos/ acompanhamento_porto_utilizacao_sensores.pdf

Vaz-Freire L. Gomes da Silva MDR, Costa Freitas AM. 2009. Comprehensive Two-Dimensional Gas Chromatography for Fingerprint Pattern Recognition in Olive Oils Produced by two Different Techniques in Portuguese Olive Varieties Galega Vulgar, Cobrançosa e Carrasquenha. Anal. Chim. Acta 633, 263-270.

Vaz Freire L, Gouveia JM, Costa Freitas AM. 2008. Analytical characteristics of olive oils produced by two different extraction techniques, in the Portuguese olive variety Galega Vulgar. Grasas Aceites 59, 260-266.
Vekiari SA, Oreopoulou V, Kourkoutas Y, Kamoun N, Msallem, M, Psimouli V, Arapoglou D. 2010. Characterization and seasonal variation of the quality of virgin olive oil of the Throumbolia and Koroneiki varieties from Southern Greece. Grasas Aceites 61, 221-231.

Verrelli GM. 2008. Electronic Tongue systems for food and environmental applications. University of Rome Tor Vergata, Department of Electronic Engineering, Sensorial and Learning Systems Engineering XX Cycle. 210p.

Vichi S, Pizzale L, Conte LS, Buxaderas S, LópezTamames E. 2003. Solid-Phase Microextraction in the Analysis of Virgin Olive Oil Volatile Fraction: Modifications Induced by Oxidation and Suitable Markers of Oxidative Status. J. Agric. Food Chem. 51, 6564-6571. 